\title{
How Blockchain Technology Changes Government: A Systematic Analysis of Applications
}

\author{
Charalampos Alexopoulos, University of the Aegean, Greece \\ Yannis Charalabidis, University of the Aegean, Greece \\ Michalis Avgerinos Loutsaris, University of the Aegean, Greece \\ Zoi Lachana, University of the Aegean, Greece
}

\begin{abstract}
It is widely argued that blockchain technology (BCT) is one of the most promising trends nowadays. The most prominent characteristic of this technology is the improved sense of trust to the shared information provided by BCT applications as well as the ubiquitous access to the data ledger. At the same time, governments pursue amplified trust from their citizens, increasing transparency through shared information and open data. Since BCT supports this strategic goal of governments worldwide, numerous governments try to capitalize on the advances of this technology through testing the results of pilot applications in different vertical governmental sectors. Even though there are several implementations in the government sector, there is no comprehensive study towards the analysis of the major characteristics of these developments. This paper moves towards the fulfillment of this gap by conducting a thorough analysis of e-government pilot applications of BCT at a European level providing information to policymakers and practitioners about the grey areas of this technology.
\end{abstract}

\section{KEYWORDS}

Blockchain Technology, Digital Governance, Digital Government, Digital Transformation, Distributed Ledger Technologies

\section{INTRODUCTION}

The new recognized generation of Digital Government, e-Government 3.0 (Lachana et al., 2018) refers to the use of disruptive ICTs such as big data, blockchain technologies and artificial intelligence technologies in combination with established ICTs such as distributed technologies for data storage and service delivery and the wisdom of crowd (crowd-sourcing and co-creation) towards data- driven and evidence-based decision and policy making (Nam, T., 2015; Song I. K., 2014). Previous research conducted in the context of the Sonnets Project (2015) is mapping the disruptive technologies against their transformative capacity within the public sector. It is indicated that currently the most hyped technology is BCT. BCT is a type of Distributed Ledger Technologies (DLT) and the underlined technology behind Bitcoin, both introduced and implemented by Nakamoto (2008). Hou H. (2017) defines BCT as ".... a distributed ledger that maintains a continually growing list of publicly accessible records cryptographically secured from tampering and revision”.

Zhang, F. et al. (2016) compares BCT to a creation of a persistent, immutable, and ever-growing public ledger that can be updated to represent the latest state of it. It was originally used to record 
historical transactions of encrypted digital currencies, such as bitcoin (Zhu H., Zhou Z. Z, 2016) and smart contract platforms like Ethereum. However, BCT is much more than enablers of cryptocurrencies: a BCT can be thought of as a distributed record of any type of transactions between parties, where transactions are validated and recorded in chronological order (in a sequence of "blocks" hence the name) by a decentralized network of peers (Antonopoulos, A.M., 2014), without need for a central/trusted/third party. The disruptive potential of BCT stems from its capability to facilitate peer-to-peer transactions without intermediaries, while at the same time validating and keeping a permanent public record of all transactions. As Zheng et. al (2016) mentioned, "Although Bitcoin is the most famous application of blockchain, blockchain can be applied into diverse applications far beyond cryptocurrencies".

Answering to the major demand of governments for enhanced trust and transparency through its unique characteristics, BCT offer a great potential for their use in the public sector. Since any transaction can be completed without the use of any intermediary (Foroglou, G., \& Tsilidou, A. L., 2015), Blockchain is a promising solution for a variety of services (Narayanan, A., et al., 2016) such as smart contracts (Ahmed Kosba et al., 2016), general public services like voting procedures and awarding subsidies (Benjamin W. Akins et al., 2013), since Blockchain can improve the security of "core government data" (Nielsen, M. M., \& Krimmer, R., 2015), Internet of Things (IoT) (Zyskind, G., \& Nathan, O., 2015), reputation systems (Morabito, V., 2017) and security services (Noyes, C., 2016). Blockchain is cited as a promising technology especially for public services (Mike Sharples and John Domingue, 2015) that could influence society or even businesses (Webb, A., 2015). By using a P2P network BCT is considered as the best solution so far for transactions between system's actors (called nodes) while storage of these transactions in a distributed way is a fact (Back, A. et al., 2014). One of the most important processes is the consensus mechanism, which is an agreement by a selected number of nodes that indicates the next block that should be added (Van Valkenburgh et al., 2016). BCT constitutes a safe technology since any transaction which takes place can be stored and cannot be removed, enabling all nodes to track the history. Distributed ledger is the usage of different nodes in order to store transaction information (Ølnes, $S$ et al., 2017). Digital signature is a combination of private key and transaction's data (for example owner of the assets). Public keys and digital signatures are being used in order for a safe transaction to be completed (Warburg, B., 2016).

While the private sector's BCT applications are exaggerating, high interest has emerged for their utilisation in the public sector as well. Considering BCT's great potential of use, it is clear to governments (including organizations and policy makers) that by including this technology into their strategies they could gain as a result a significant advantage in a fast change eco-system. As it has been stated in (Engelenburg, S.v. et al., 2017) a number of recent studies argue that Distributed Ledger Technologies (DLT's) can also significantly contribute in making the public sector a faster, more open, trusted party, while unlocking the potential of citizens and enterprises, towards a more collaborative, yet managed, ecosystem of services. The ability to record transactions on distributed ledgers offers new approaches for governments to address societal, business or public sector needs as faster and transparent access to public sector services, prevent fraud and establish trust. BCT implementations are largely technology driven and often various combinations of technologies are needed to make the BCT architecture ðt for e-Government applications (Engelenburg, S.v. et al., 2017). The importance of this technology is also documented by various studies conducted by EU Parliaments on virtual currencies (VCs) and BCT (European Parliament, 2016), as well as the creation of a task force dedicated to cryptocurrencies and BCT (Kastelein, R., 2016). Moreover, the summer of 2017 opened a call for proposals to set-up a European Expertise Hub on BCT and Distributed Ledger Technologies (European Commission, 2017). Among the rest of the EU initiatives, the European Commission is seeking submissions for a new BCT development contest with a $5 \mathrm{M}$ Euros top prize (De, Nikhilesh., 2017) and is launching a study aimed to assess the feasibility and potential of an EU- wide infrastructure (Sundararajan, Sujha., 2017). Similarly, the US Congress has launched the so-called Congressional BCT Caucus on 26 September 2016 (Polis, J., 2016). 
However, since the field is still in its infancy, a series of challenges exist, which call for further investigation. Therefore, it is necessary to analyse BCT from various perspectives in order to gain a better understanding of its potential, as well as the factors that determine its adoption in the public sector. Our paper contributes towards this direction. It uses documentary analysis to identify the current implementations of BCT in the public sector. Through the analysis framework, it provides results for many different aspects of the technology under study and how it is applied in different cases elucidating the current landscape of BCT implementations in the public sector.

This paper consists of six sections. The following section 2 presents the relevant research conducted in this domain along with its major results. In section 3, the methodological approach and the analysis framework are presented. Section 4 contains the basic results of the study and discusses important findings and the implications to policy makers. Section 5 concludes the paper.

\section{RELEVANT RESEARCH}

Different scholars provide literature reviews of the use of BCT in government. Ølnes (2016) shows that the majority of articles dealing with BCT focus primarily on the technology behind bitcoin and until 2015 there are few publications relative to BCT in Government in the literature databases (including bitcoin, crypto currency technology, eGovernment, electronic Government, e-Government e.tc). The author suggests that in order to be a potential valuable technology for use in public sector BCT needs to be more than a payment solution.

European public administrations have committed serious efforts the last years, in order to advance the automation and sophistication of digital services towards citizens and enterprises. It is however clear that some important issues concerning the openness and trustworthiness of information, the interoperability among different systems and processes, as well as the quality and speed of certain governmental services have still a long way to go. Public sector modernization addresses the permanently increasing need for higher quality and more efficient public services. The digital transformation of public administrations is the key element in the European strategy for it. It reduces the costs of public administrations and makes their services more transparent and convenient for businesses and citizens. It helps to achieve new economic and societal benefits and reduce administrative burdens across the European Union towards the Single European Market.

The current guiding instrument joining up efforts towards modernisation of public administrations in the EU is the eGovernment Action Plan for 2016-2020 ${ }^{1}$. It targets to initiatives that will not just help to "design and deliver better services in line with the needs and demands of citizens and businesses" but will create greater transparency and accountability of public administrations "using the opportunities offered by the new digital environment to facilitate their interactions with stakeholders and with each other". This is prominent also in the Digital Single Market strategy which aims to continue pursuing efforts towards the transformation of the public sector: "Public services in Europe have embraced new technologies to varying degrees but more can be done to modernise public administration, achieve cross-border interoperability and facilitate easy interaction with citizens"2.

Generally, as OPSI (2018) mentioned BCT has three goals to be achieved. These goals are: (a) Reduce or Eliminate the need of a central authority, (b) Eliminate central points of failure and (c) Enable trust among people who do not know each other to directly conduct transactions. Furthermore, Hou H. (2017) reveals that BCT can bring many benefits, including improvements in the quality and quantity of Government services by the simplification of the majority of Government processes, such as bureaucratic processes, Government information with greater transparency, open and accessible Government information to citizens and businesses including information-sharing across different organizations development, and even assistance in building an individual credit system. Citizens and businesses can easily gain access to government's information thus government's credibility could be improved by using BCT platforms (E Zhang, 2018) and data safety (Gervais, A. et al., 2016) in every transmission could also be part on every transaction among any authorized party including 
participant's anonymity by the usage of encryption keys (Böhme et al., 2015). Moreover, storing any secured information using BCT constitutes a profitable solution for public services. Thus, offered Government services could be personalized and borderless, transforming society into a more collaborative one (OPSI, 2018; Zhang, F., 2016).

In terms of challenges, scalability consists an important impediment, since only seven transactions per second can be processed. If we consider BCT as a payment solution used by Government with a requirement of processing millions of transactions, many of these transactions might be delayed. Although, BCT uses public keys hidden of any transaction there might be safety challenges including information leakage (Zheng, Z. et al., 2016). As a matter of fact, the above-mentioned challenge arises because of the lack of the actual time priority in a transaction process (until the validation of a transaction) and in the distributed ledger itself. Another challenge reported by Zheng et al. (2016) is Selfish Mining. While selfish miners trying to hack the chain, not only nodes with more than a half $(51 \%+)$ computing power can reverse a transaction, but it is shown (Ittay Eyal and Emin Gün Sirer, 2014) that also around the half computing power is dangerous. Another challenge which is faced by the usage of BCT is the impression that only the trust of the technology is enough for a system to be safe. As Hou H. (2017) mentioned "At present, a danger actually comes not from system vulnerabilities, but from blind trust in the blockchain on the part of blockchain developers, lawmakers, law enforcement and the general public. This trust relies exclusively on the technology, rather than management, to make sure the system is trusted and the records in the system are reliable". Alternatively, authentication can be offered to be valid in one country for instance e-IDs, but they are not necessarily legally binding in any other nation state. Moreover, as Sullivan (Sullivan, C., \& Burger, E., 2017) mentioned “...there is the risk that identity information authenticated on the Blockchain, but which is otherwise invalid may find its way into traditional channels to enable creation of new, false identities, which could then be used to hide one's real identity". A noteworthy study in this direction is the one of Batubara (Batubara, F. R, 2018), identifying the adoption barriers of BCT to the public sector. In this study some of the most important beneficial characteristics of BCT application in government have been discussed revealing the underlying impediments.

As it was noted BCT is often used as a solution for the improvement of public services. Recent case studies include BCT for digital payments (Kastelein, R., 2016), providing academic certificates stored on the BCT at the University of Nicosia (Narayanan, A., 2016), a sovereign government backed identity credential as a pilot (e-ID card) in Dutch (Alexandre A., 2018) and healthcare, pensions, Government performance, food safety and Government divisions, all of which have close relationships with individuals' livelihood in China (Gervais, A., et al., 2016). Furthermore, Dubai's government aims at utilising BCT to transform its internal and external transaction services digitally. According to the Dubai Blockchain strategy (2018), Government believes that adopting blockchain technology will save 5.5 billion dirhams. Also, NCSL (2017) estimates that 10 percent of global GDP will be stored on BCT by 2027.

A recent survey conducted by IBM (2017) and the Economic Intelligence Unit, that 7 out of 10 Government executives predict BCT will significantly disrupt the area of contract management, while $14 \%$ of Government organizations expect to have BCT in production and at scale in 2017 . The same study indicates that 9 out of 10 Government organizations plan to invest in BCT for use in financial transaction management, asset management, contract management and regulatory compliance by 2018. Market sectors that already indicate compelling applications of BCT include finance, real estate, voting systems, healthcare and shipping. The innovation potential in the above sectors emerges from the merits of blockchain on security, privacy, transparency enhancement and fraud prevention. Furthermore, BCT keeps sensitive information (personal, business etc) secured and private, allowing an unmediated process of a transparent and indestructible activity. Among the compelling cases of using blockchains to innovate existing markets and processes are: finance (e.g., redesigning clearing and settlement systems), real estate (create tamper-proof records of home/land ownership), voting (increasing transparency and combating fraud), health (enabling individuals, health care providers, 
and medical researchers to securely share electronic health data, without compromising on patient privacy), shipping (using blockchains to streamline and secure cross-border supply chain operations), and many others.

\section{METHODOLOGICAL APPROACH AND ANALYSIS FRAMEWORK}

This section presents the methodological approach of our study towards the review of the current landscape of BCT in e-Government. Based on the documentary analysis, we seek to produce shreds of evidence for substantiating our research claims. The documentary analysis could be defined as "a systematic procedure for reviewing or evaluating documents-both printed and electronic (computerbased and internet-transmitted) material" (Zhu H., Zhou Z. Z., 2016). We used documentary analysis in order to categorize, investigate and identify written documents from the conducted literature review, whether in the private or public domain (personal papers, commercial records, or state archives, communications, or legislation (Payne, G. and Payne, J, 2004). During this research, we tapped both online and offline records indicating the usage of the BCT in the public sector.

The following figure (Figure 1) depicts the methodological approach. We first conducted a literature review that enabled us to assemble the basic dimensions and factors upon which the analysis framework was developed underlying the different aspects of the analysis. To be more precise the Google Scholar literature search engine was used. Eight (6) keywords were used to search scientific articles: (1) blockchain solutions e-government, (2) blockchain electronic government, (3) blockchain digital government, (4) blockchain e-governance, (5) blockchain electronic governance, (6) blockchain digital governance. Quotation marks were used in all cases to search for an exact phrase but only to the keyword's second part. For example, regarding the keyword blockchain electronic governance the blockchain "electronic governance" keyword was used while the "blockchain" electronic governance was excluded. In addition, inclusion - exclusion criteria were applied during this step regarding the studies' year of publication. We focused on studies which their published duration was from 2016 to mid-2020. In parallel, we examined a random sample of 105 publications in order to confirm that the extracted scientific papers were as desired and expected for this study. This step was conducted during the midyear 2019 and resulted to 3,729 scientific papers.

Figure 1. Methodological approach

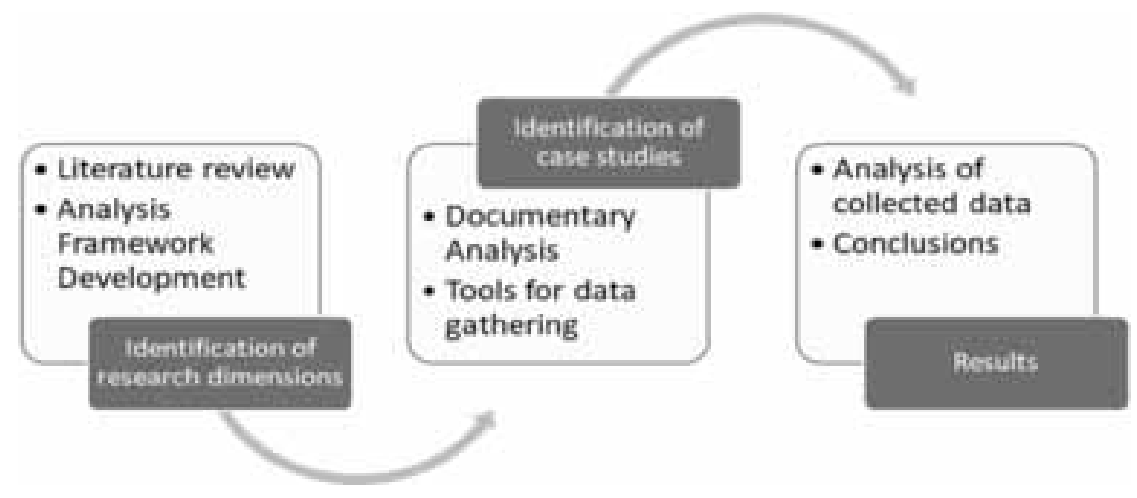

As a second step, we proceeded to a desk-based research detecting the cases under investigation. This step of our methodology consists of the identification of running projects relevant to e-government by reviewing public and private sector documents about the results and the aims of the identified projects. For this step to be conducted the Google search engine along with the European tool CORDIS 
(Community Research and Development Information Service) were used. The same (six) mentionedabove keywords were used for the conduction of this step. The research conducted in Cordis resulted in 22 projects while in Google in 19 more.

Then, we continued with the task of analysis conducting the major outcomes and results of our study and highlighting important issues that are discussed in section 5. An initial screening of the search results was performed based on the title of each publication, the keywords associated with the publication and the abstract. The initial screening resulted to 2,147 studies. A more detailed review was then conducted on the remaining publications by applying inclusion exclusion criteria (in a form of questions) that focus on the performance of blockchain in the public sector and studies published only in English. Particularly, these criteria are:

1. Does this paper adequately analyse (not as a simple reference) the usage of the BTC in the public sector? This criterion resulted in a new categorization of the identified scientific papers into three (3) types based on their content: (1) Scientific papers which analyse the theoretical background (a more theoretical perspective) of the adoption of the BCT in the public sector. These kinds of papers analyse all the aspects of the BCT, including (among all) the BCT types, characteristics, usage, the benefits that a government or the private sector can gain by adopting a BCT solution, and the barriers that they may face by adopting them. (2) Scientific papers that address the BCT in the aspects of governments. It was clearly stated in the abstract and the introduction section of these papers that the conducted research concerns only the public sector. Finally, the third type includes (3) scientific papers whose approach concerns only the private sector. Although they analyse all the above-mentioned BCT aspects (included both in 1st and 2nd types), their viewpoint concerned only the private sector. These criteria and with the exclusion of the third type, resulted in 1,421 scientific papers, some of which raise issues regarding the adoption of the BCT in the public sector, while others present a more technical aspect of the BCT.

2. If it concerns an initiative, is any government involved? This criterion hides two main aspects. The first aspect that needed to be examined was the identification of any referred BCT initiative while the second aspect revealed the initiatives in which governments are involved in their implementation. The second aspect's examination resulted in 162 scientific papers.

3. Is there enough information to understand the purpose/ the aim of the initiative? The third criterion concerns the analysis of the identified initiatives. The remaining scientific papers along with the results of the 2nd methodological step were manually examined and analysed on the basis of the analysis framework factors. Out of the total of 41 initiatives, 26 were kept along with 104 scientific papers.

The analysis framework consists of various factors towards landscaping the use of the technology in the domain of e-Government. These factors combine the theory of BCT (Section 2) along with the gathered information of the involved governments (methodological steps $2 \& 3$ ). In addition to the general information, (e.g., governments that adopted the identified initiatives, the application level, and the technological readiness level) the type of BCT is of major importance for landscaping the use of the BCT in the domain of e-Government. In order to clarify which type each initiative uses, it was necessary to fully analyse the results of the identified scientific papers (methodological step 3) along with each initiative. The factors of the analysis are presented as follows:

- Implementation Partners: The implementation partner is the firm, the (public) organisation or the consortium took over the development of the BCT solution. In most of the cases this is a company dedicated in sectoral implementations of BCT.

- Government: The country (and the city in relevant cases) which implemented the solution. 
- Application Level: The application level is supposed to investigate the coverage of the identified solution and consists of 3 distinct values, namely: national, regional, municipal and organisational (covering internal procedures).

- BCT Type: there are more than one categories/types for current BCT systems. Buterin (2014) and Zheng et al.(2016) distinguish three types which are (1)public BCT, (2)private BCT and (3) consortium BCT while Ølnes et al (2017) stated that BCT systems can be viewed into two basic types (1) private BCT or (2) public BC including their subcategories which are either open/ permissionless or closed/permissioned. The two types of ledger's condition, i.e. private/closed or public/open determine who has access to copies of the ledger while the characterization of permissioned or permissionless determines who maintains the ledger. Furthermore, the consensus determination is the mechanism which validates the next block. In public permissionless BCT each node can participate in the process, while in public permissioned BCT and in private permissionless BCT a selected set of nodes. Private permissioned BCT is fully controlled by the owner. Read permission determinize whether stored transactions are restricted or can be viewed and immutability determinizes the possibility of the BCT to be tampered. Efficiency is the key which shows the velocity of any transaction. The number of participant nodes defines the centralization of a chain, less nodes means centralized or partial centralized. Finally, consensus process specifies permissions among the chain.

- Technology Readiness: The technology readiness level could be measured by assigning the following 3 values: Proof-of-concept, Pilot, Large-Scale Implementation and Production Level Large-Scale Implementation.

- Domain: The domain factor acknowledges the application domain of the identified solution. It could take values that respond to governmental services and/or domains.

- Impact type: The impact type detects the potential impact category of the identified application. The allowed values are: Social, Environmental, Economic, and different combinations of them.

- About: This field maintains the qualitative characteristics and a description of the identified solution.

\section{RESULTS AND DISCUSSION}

This section analyses the results of conducted study. Twenty-six cases have been identified across Europe. The following table presents the identified solutions of BCT applied in the e-Government domain.

The continuously growing number of BCT initiatives that are being adopted in the public sector by various states is a strong indicator of the current trend advocating the utilization of key BCT capabilities in the respective services. The adoption of BCT by the Estonian government (Martinson, P., 2019) is the more advanced example of the exploitation of the technology in the public sector. Specifically, the Estonian e-Government approach is built around a service-rich ecosystem consisting of approximately 3000 services including identity management, tax collection, voting, etc. Similar initiatives have been also implemented by other states -although at a narrower scale in terms of number of services- such as the United Kingdom, where services like welfare payments are powered by BCT. The full list of the identified BCT applications in EU is presented in the Table 1 (Appendix A).

In general, the use of BCT in the public sector is still limited to few relevant cases. The most relevant cases are reported in the table of the appendix A that presents a short list of BCT solutions for the public sector. BCT represent a core segment of technology innovations that create significant opportunities for a major and disruptive refresh of a wide spectrum of infrastructure and applications. The following figures (2-5) present the basic elements of the analysis.

Furthermore, the analysis of these BCT applications results in the following observations: 
International Journal of Public Administration in the Digital Age

Volume $8 \cdot$ Issue $1 \cdot$ January-March 2021

Figure 2. Percentages of the different application level of the identified solutions

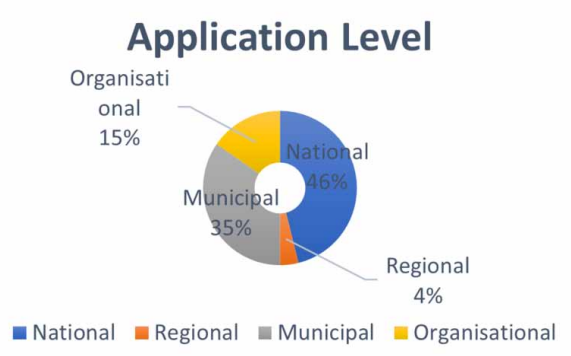

Figure 3. Percentages of the BCT types used in the identified cases

\section{BCT Type}

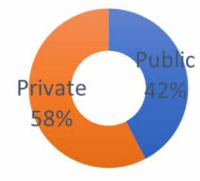

- Public Drivate

Figure 4. Percentages of the technology readiness in the identified cases

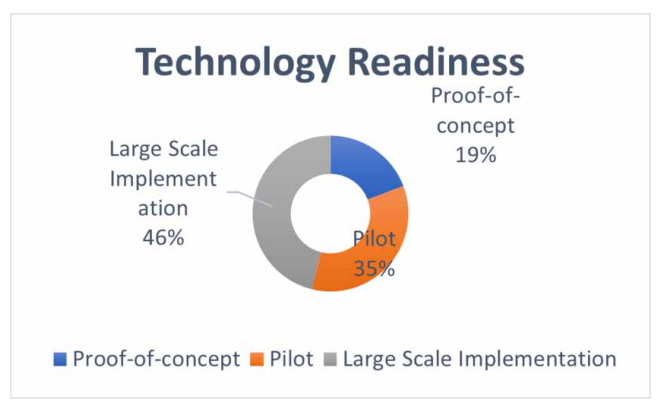

Figure 5. Percentages of the impact types of the proposed solutions

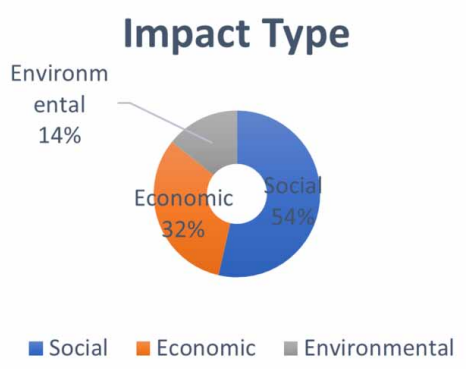


- The applications have covered a lot of domains: health records, identity management, land registry, document exchange and file management, fake news detection, allowances and subsidies, waste management, payments, immigration, e-voting and academic certificates. The majority of the applications are dealing with allowances and subsidies, e-voting and land and health registries. The newest domains of applying BCT are: (a) waste management and (b) fake news detection.

- The majority of BCT implementations in the EU area results from partnerships with private companies, undertaking the role of technology providers that implement BCT based solution to governments.

- The innovators countries in the domain of BCT running an e-government project are located in the Northern and more specifically in the North-western Europe (Netherlands, Belgium, Estonia, Switzerland, Finland, United Kingdom, Luxembourg, Norway, Sweden), while 3 countries are located in the Southern and South-western Europe (Malta, Spain, Italy).

- In terms of specific countries, The Netherlands has the lead with 5 pilot initiatives/ projects, followed by UK with 1 large scale implementation and 2 ongoing proof of concepts, Estonia with 2 production level large scale implementations, and Italy and Switzerland holds the fourth place with 1 large scale implementation and 1 ongoing proof of concept.

- In terms of BCT types that are used in the identified cases, the private BCT type holds $58 \% .46 \%$ of the solutions are applied nationally, while $35 \%$ at municipal and $15 \%$ at organizational levels.

- The applications and/or case studies could be categorised in three different groups according to their Technology Readiness Level: (a) large-scale implementations (46\%) with $43 \%$ of them being at production level, (b) pilot applications (35\%) most of them completed and (c) proof of concept (19\%) with most of them ongoing.

- In terms of impact the identified types are: (a) Social (54\%); (b) Economic (32\%) and (c) Environmental (14\%), with a few cases presenting both economic and environmental impact.

- The applications and/or case studies utilise both public and private BCT regardless of their scope. For example, identity management and land registry projects utilise both public and private ones. Projects dealing with health records utilising private BCT implementation.

- There are different levels of initiatives extension. They are applied at the organisational, municipal and national level. The majority of the case studies have been implemented at national level. There is no correlation between the level of extension and the type of application according to their TRL level. Some large-scale implementations applied to the national level while other national implementations have developed proof of concept. This probably depends on the experience of the staff involved and the orientation of national governments towards the adoption of innovation (i.e. how much they trust or are convinced about the benefits of the new BCT).

Further to the above analysis, some important considerations for public servants and policy makers working with this technology are discussed in this section. These considerations were identified during the procedure of the current research based on the documents and data collected for this study.

Despite blockchain constitutes a transformative technology and not a political one, its political implications are significant, considering technology affords which can reconfigure ultimately broader socio-political relationships such as legal, institutional even economic. BCT has been called 'the WorldWide Ledger 'by D. Tapscott, who maintains that' with its advent, we will not need to trust each other in the traditional sense because trust is built into the system itself" 3 - a truly revolutionary phenomenon that the Economist has called "the trust machine"4. The phenomenon will have profound consequences for the world, just like the Internet had a couple of decades ago, enabling new forms of finance (digital currencies, like Bitcoin), new forms of commerce (such as machine-to-machine transactions), and new forms of economic organization (such as decentralized autonomous organizations).

This disruptive potential, coupled with the complex and far-reaching nature of blockchains, has created significant interest and research on them. Governments, public policymakers, and organizations 
are formulating blockchain engagement strategies, realizing that, those that do so first, will gain a significant advantage in this fast-changing ecosystem. According to Rep. Jared Polis (D-Colo.) $)^{5}$, 'the blockchain has boundless potential: from cryptocurrencies to supply chains to banking to property titling, blockchain-based solutions have the ability to decentralize cybersecurity and revolutionize many industries. It's vital for Americans, businesses, and members of Congress to learn about blockchain so the U.S. can continue to secure its stance as the global leader of ingenuity'.

At the same time, central banks and financial services authorities are also actively researching blockchains. For instance, the Federal Reserve chairwoman Janet Yellen has reportedly 'encouraged her fellow central bankers to accelerate their studies of new financial technologies, specifically mentioning bitcoin, the blockchain, and other distributed ledgers' in a closed-to-the-press event, attended by representatives from more than 90 central banks in June 2016 ${ }^{6}$. Similarly, the European Central Bank has stated that it "intends to assess their ["blockchain" or "distributed ledger technologies"] relevance for the different services it provides to the banking communities (payments, securities settlement as well as collateral) $)^{7}$.

Considering all BCT's benefits and challenges, it is important to understand whether the use of a technology such BCT is important in the domain of e- Government and if so in which sectors. Careful consideration on the use of BCT should be given in the cases the GDPR right to be forgotten is applied. It is pointed out that even bank records could be deleted after five years. The conflict between GDPR (2017) and BCT raises important legal considerations for public and private sector seeking to implement blockchain solutions that involve personal data (Kramer, N., 2018). Data immutability (Pilkington, M., 2019), a key feature of the BCT is against the new requirements of the GDPR especially the erasure right (Safari, B. A., 2016), which demands the erase of the personal data of individuals when they request to be "forgotten" (Kramer, N., 2018). Another issue is the complicating GDPR's definition of "personal data" which defines them as any information relating to a natural person, either identified or even identifiable, who can be directly or indirectly identified by reference to an identifier such as a name or an identification number (Kramer, N., 2018; Pilkington, M., 2019; Safari, B. A., 2016). Some experts (Kramer, N., 2018; Pilkington, M., 2019) believe that a cryptocurrency wallet address can be considered as personal data due to GDPR is it is publicly available.

All the identified types of application as well as the benefits and obstacles coming from them should be proven and addressed through impact analyses and thorough examination of current and future applications. This study reports on the non-existence of evidence regarding the enhancement of trust and interoperability. Also, there is no evident correlation among the service and type of BCT used in each case. Most of the cases are either pilots or proof-of-concepts trying to provide some evidence towards greater adoption, but no generalizations could be concluded even about the type of BCT used in specific cases.

Finally, the preferable type of BCT is private since public administrations need to maintain the control of the blockchain and to tackle scalability issues. Additionally, the current application scenarios are focusing on the usage of BCT in many different services that present transactional and registry functionality.

\section{CONCLUSION AND FURTHER RESEARCH}

This study has conducted an analysis landscaping the use of BCT in the public sector. Our findings indicate that BCT is starting to be used as an enabling array of technologies that can contribute to the openness and transparency of services in the public sector for many different services. Newest application scenarios could allow even waste management and fake news detection, as well as immigrants' new identities and health records that could never been falsified. At the level of public administrations, record keeping constitutes the most widely used application area of BCT due to a series of advantageous technical properties related to the creation/verification of records, namely, speed, security, and transparency. Furthermore, this study concludes on the following issues: (a) there is no 
standard way of implementing BCT in the public sector; (b) the preferable BCT type is the private one, since it offers better control and avoids scalability issues and (c) most of the current cases of $\mathrm{BCT}$ in the public domain have applied to services presenting transactional and registry functionality.

Finally, it is evident that more research towards the evaluation of the applied scenarios is needed towards the identification of strong and weak points of these cases. Future studies need to investigate, evaluate and confirm the importance of using this emerging technology by governments. What are the gained benefits from the application of this technology? Why this type of BCT is selected? To what extend citizens' trust will be influenced by the adoption of this technology? To what extend employees accepted the adoption of this technology? To what extend the use of this technology will help governments to struggle against fraud? Which is the effect of enabling and supporting (including Government's existing infrastructures) this technology? 


\section{REFERENCES}

Kosba, A., Miller, A., Shi, E., Wen, Z., \& Papamanthou, C. (2016). Hawk: The blockchain model of cryptgraphy and privacy-preserving smart contracts. Proceedings of IEEE Symposium on Security and Privacy (SP), 839-858. doi:10.1109/SP.2016.55

Alexandre, A. (2018). R3 Partners With Dutch Tech Company to Pilot Blockchain-Based Digital IDs. https:// cointelegraph.com/news/r3-partners-with-dutch-tech-company-to-pilot-blockchain-based-digital-ids

Antonopoulos, A. M. (2014). Mastering Bitcoin: Unlocking Digital Crypto-Currencies. O’Reilly Media.

Atzori, M. (2015). Blockchain technology and decentralized governance: Is the state still necessary? Academic Press.

Back, A., Corallo, M., Dashjr, L., Friedenbach, M., Maxwell, G., Miller, A., . . Wuille, P. (2014). Enabling blockchain innovations with pegged sidechains. Open Science Review. https://www.blockstream.ca/sidechains. pdf)

Batubara, F. R., Ubacht, J., \& Janssen, M. (2018, May). Challenges of blockchain technology adoption for e-government: a systematic literature review. In Proceedings of the 19th Annual International Conference on Digital Government Research: Governance in the Data Age (pp. 1-9). doi:10.1145/3209281.3209317

Akins, Chapman, \& Gordon. (2013). A whole new world: Income tax considerations of the bitcoin economy. Academic Press.

Böhme, R., Christin, N., Edelman, B., \& Moore, T. (2015). Bitcoin: Economics, Technology, and Governance. The Journal of Economic Perspectives, 29(2), 21338. doi:10.1257/jep.29.2.213

Buterin, V. (2014). Ethereum White Paper: A nextgeneration smart contract and decentralized application platform. Ethereum White Paper.

De, N. (2017, November 10). EU Officials Reveal E5 Million 'Blockchains for Social Good' Contest. Retrieved from https://www.coindesk.com/eu-officials-reveal-e5million-blockchains-social-good-contest/amp/

Dubai Blockchain Strategy. (2018) https://smartdubai.ae/en/Initiatives/Pages/DubaiBlockchainStrategy.aspx

Zhang, E. (n.d.). Antshares Whitepaper1.0. Available at: https://github.com/AntShares/AntShares/wiki/ Whitepaper1.0

Engelenburg, S. v., Janssen, M., \& Klievink, B. (2017). Design of a software architecture supporting business-to government information sharing to improve public safety and security: Combining business rules, events and blockchain technology. Journal of Intelligent Information Systems.

EUGDPR. (2017). The EU General Data Protection Regulation. GDPR.

European Commission. (n.d.). EU Blockchain Observatory and Forum.

European Parliament. (2016). 2.50.04.02 Electronic money and payments, cross-border credit transfers. Author.

Foroglou, G., \& Tsilidou, A. L. (2015). Further applications of the blockchain. 12th Student Conference on Managerial Science and Technology.

Gervais, A., Karame, G. O., Wüst, K., Glykantzis, V., Ritzdorf, H., \& Capkun, S. (2016). On the security and performance of proof of work blockchains. In Proceedings of the 2016 ACM SIGSAC conference on computer and communications security (pp. 3-16). ACM doi:10.1145/2976749.2978341

Hou, H. (2017, July). The Application of Blockchain Technology in E-Government in China. In Computer Communication and Networks (ICCCN), 2017 26th International Conference on (pp. 1-4). IEEE.

IBM. (2017). Four Ways Blockchain Could Aid Governments. https://www.ibm.com/blogs/think/2017/01/fourways-forblockchain/

Eyal, I., \& Sirer, E. G. (2014). Majority is not enough: Bitcoin mining is vulnerable. Proceedings of International Conference on Financial Cryptography and Data Security, 436-454. doi:10.1007/978-3-662-45472-5_28 
Kastelein, R. (2016, May 30). EU Parliament Approves Blockchain and Cryptocurrency Task Force. Retrieved from https://www.the-blockchain.com/2016/05/30/eu-parliamentapproves-blockchain-and-cryptocurrencytask-force/

Kramer, N. (2018, April 17). Blockchain, Personal Data and the GDPR Right to be Forgotten. Retrieved from https://www.blockchainandthelaw.com/2018/04/blockchain-personal-data-and-the-gdpr-right-to-be-forgotten/

Lachana, Z., Alexopoulos, C., Loukis, E., \& Charalabidis, Y. (2018, September). Identifying the different generations of Egovernment: an analysis framework. In The 12th Mediterranean Conference on Information Systems (MCIS) (pp. 1-13). Academic Press.

Martinson, P. (2019). Estonia-The Digital Republic Secured by Blockchain. PricewaterhouseCoopers.

Sharples, M., \& Domingue, J. (2015). The blockchain and kudos: A distributed system for educational record, reputation and reward. Proceedings of 11th European Conference on Technology Enhanced Learning (EC-TEL 2015), 490-496.

Morabito, V. (2017). Blockchain Governance. In Business Innovation Through Blockchain (pp. 41-59). Springer. doi:10.1007/978-3-319-48478-5_3

Nakamoto, S. (2008). Bitcoin: A peer-to-peer electronic cash system. Academic Press.

Nam, T. (2015). Challenges and Concerns of Open Government: A Case of Government 3.0 in Korea. Social Science Computer Review, 33(5), 556-570. doi:10.1177/0894439314560848

Narayanan, A., Bonneau, J., Felten, E., Miller, A., \& Goldfeder, S. (2016). Bitcoin and Cryptocurrency Technologies: A Comprehensive Introduction. Princeton University Press.

NCSL. (2017). Blockchain Technology: An Emerging Public Policy Issue. LegisBrief (vol. 25 no. 44). https:// www.ncsl.org/documents/legisbriefs/2017/lb_2544.pdf

Nielsen, M. M., \& Krimmer, R. (2015, May). Reuse of Data for Personal and Proactive Service: An Opportunity Not Yet Utilised. In CeDEM15: Conference for E-Democracy and Open Government (Vol. 273). MV-Verlag.

Noyes, C. (2016). Bitav: Fast anti-malware by distributed blockchain consensus and feedforward scanning. arXiv preprint arXiv:1601.01405.

Ølnes, S. (2016, September). Beyond bitcoin enabling smart government using blockchain technology. In International Conference on Electronic Government and the Information Systems Perspective (pp. 253-264). Springer. doi:10.1007/978-3-319-44421-5_20

Ølnes, S., Ubacht, J., \& Janssen, M. (2017). Blockchain in government: Benefits and implications of distributed ledger technology for information sharing. Government Information Quarterly, 34(3), 355-364. doi:10.1016/j. giq.2017.09.007

OPSI. (2018). Blockchain and its Use in the Public Sector. https://oecd-opsi.org/wp-content/uploads/2018/06/ Blockchains-Unchained-Slides.pdf

Payne, G., \& Payne, J. (2004). Key Concepts in Social Research. Sage. doi:10.4135/9781849209397

Pilkington, M. (2016). 11 Blockchain technology: principles and applications. Research handbook on digital transformations, 225.

Polis, J. (2016, September 26). Polis launches Congressional Blockchain Caucus. Retrieved from http://polis. house.gov/news/documentsingle.aspx?DocumentID=398230

Safari, B. A. (2016). Intangible Privacy Rights: How Europe's GDPR Will Set a New Global Standard for Personal Data Protection. Seton Hall Law Review, 47, 809.

Song, I. K. (2014). Emerging Internet Technology \& Service toward Government 3.0. KSII Trans. Internet Inf. Syst., 8(2), 540-546. doi:10.3837/tiis.2014.02.012

SONNETS. (2015). Policy Maker Content - Related Recommendation. http://www.sonnetsproject.eu/sites/ default/files/sonnets/public/contentfiles/article/Policy\%20Maker_Contentrelated\%20Recommendation\%205.pdf 
Sullivan, C., \& Burger, E. (2017). E-residency and blockchain. Computer Law \& Security Review, 33(4), 470-481. doi:10.1016/j.clsr.2017.03.016

Sundararajan, S. (2017, November 13). European Commission to Assess Potential of EU-Wide Blockchain Infrastructure. Retrieved from https://www.coindesk.com/european-commission-to-assesspotential-of-eu-wideblockchain-infrastructure/amp/

Van Valkenburgh, P., Dietz, J., De Filippi, P., Shadab, H., Xethalis, G., \& Bollier, D. (2015). Distributed collaborative organisations: Distributed networks and regulatory frameworks. Harvard Working Paper.

Warburg, B. (2016). How the blockchain will radically transform the economy. TEDSummitTED Talk. Retrieved from https://www.ted.com/talks/bettina_warburg_how_the_blockchain_will_radically_transform_ the_economy?language $=\mathrm{en}$

Webb, A. (2015). 8 tech trends to watch in 2016. Harvard Business Review. https://hbr.org/2015/12/8-techtrends-to-watch-in 2016

Zhang, F., Cecchetti, E., Croman, K., Juels, A., \& Shi, E. (2016, October). Town crier: An authenticated data feed for smart contracts. In Proceedings of the 2016 a CM sIGSAC conference on computer and communications security (pp. 270-282). ACM. doi:10.1145/2976749.2978326

Zheng, Z., Xie, S., Dai, H. N., \& Wang, H. (2016). Blockchain challenges and opportunities: A survey. Work Pap.

Zhu, H., \& Zhou, Z. Z. (2016, February). Analysis and outlook of applications of blockchain technology to equity crowdfunding in China. Financial Innovation, 29.

Zyskind, G., \& Nathan, O. (2015). Decentralizing privacy: Using blockchain to protect personal data. In IEEE security and privacy workshops (SPW2015) (pp. 180-184). IEEE.

\section{ENDNOTES}

https://ec.europa.eu/digital-single-market/en/news/communication-eu-egovernment-action-plan-20162020-accelerating-digital-transformation

EC, A Digital Single Market Strategy for Europe - COM(2015) 192 final, available at http://eur-lex.europa. eu/legal-content/EN/TXT/?qid=1447773803386\&uri=CELEX\%3A52015DC0192

http://blockchain-revolution.com

http://www.economist.com/news/leaders/21677198-technology-behind-bitcoin-could-transform-howeconomy-works-trust-machine

http://polis.house.gov/news/documentsingle.aspx?DocumentID=398230

http://www.americanbanker.com/news/bank-technology/yellen-reportedly-urges-central-banks-to-studyblockchain-bitcoin-1081354-1.html

http://leman.ie/european-central-bank-open-to-adopting-blockchain-technology-for-financial-services/ https://newsbreak.edu.mt/2018/03/05/thousands-of-maltese-students-to-get-their-certificates-on-

blockchain/

https://www.ethnews.com/uport-announces-zug-digital-ethereum-id-pilot

https://en.wikipedia.org/wiki/R3_(company)

https://guardtime.com/blog/increasing-healthcare-security-with-Blockchain-technology

http://blue-dun.com/2018/01/02/digital-identities-cambridge-blockchain/

https://cointelegraph.com/news/dubai-and-norway-use-blockchain-to-redefine-tourism

https://cointelegraph.com/news/swedish-government-land-registry-soon-to-conduct-first-blockchain-

property-transaction

https://procivis.ch/eid/use-cases/

https://www.ethnews.com/uk-government-considers-expanding-blockchain-trial-for-benefits

https://www.bna.com/blockchain-boost-governments-n73014477132/

https://www.opendemocracy.net/marco-deseriis-david-ruescas/agora-votingnvotes

https://reliefweb.int/report/finland/how-finland-using-blockchain-revolutionise-financial-services-refugees https://e-estonia.com/solutions/security-and-safety/e-law/

https://open.wien.gv.at/site/2-blockchain-pilot-der-stadt-wien-digitale-essensmarke/ 
https://dadesobertes.valls.cat/

https://media.wix.com/ugd/df1122_3de6de424d3b4f618af9e768e12d0ca0.pdf

https://flowbikes.io/

https://media.wix.com/ugd/df1122_3de6de424d3b4f618af9e768e12d0ca0.pdf

https://antwerpen.digipolis.be/en/blog/Blockchain-projects-in-Antwerp

https://stadjerspas.nl/

https://media.wix.com/ugd/df1122_3de6de424d3b4f618af9e768e12d0ca0.pdf

https://nidigratis.blockchainregionelombardia.it/

https://ipsoeu.github.io/ips-explorer/service/50827.html

https://www.lyon.fr/demarche/loisirs/calcul-du-quotient-familial-municipal

https://www.ansa.it/english/news/science_tecnology/2020/04/06/ansa-using-blockchain-to-help-readers_ af820b4f-0947-439b-843e-52e114f53318.html 


\section{APPENDIX A. BCT INITIATIVES IN THE DOMAIN OF E-GOVERNMENT}

Table 1. BCT Initiatives in the domain of e-Government

\begin{tabular}{|c|c|c|c|c|c|c|c|}
\hline $\begin{array}{l}\text { Implementation } \\
\text { Partners }\end{array}$ & Government & $\begin{array}{l}\text { Application } \\
\text { Level }\end{array}$ & $\begin{array}{l}\text { BCT } \\
\text { Type }\end{array}$ & $\begin{array}{l}\text { Technology } \\
\text { Readiness }\end{array}$ & Domain & Impact type & About \\
\hline Blockcerts & Malta & National & Public & Pilot & $\begin{array}{l}\text { Academic } \\
\text { Certificates }\end{array}$ & Social & $\begin{array}{l}\text { Blockcerts }{ }^{8} \text { is an open } \\
\text { standard for creating, } \\
\text { issuing, viewing, and } \\
\text { verifying blockchain } \\
\text { based certificates. }\end{array}$ \\
\hline Uport & Switzerland & Municipal & Public & $\begin{array}{l}\text { Large Scale } \\
\text { Impl. }\end{array}$ & $\begin{array}{l}\text { Identity } \\
\text { Management }\end{array}$ & Social & $\begin{array}{l}\text { uPort }^{9} \text { is a self-sovereign } \\
\text { identity system that allows } \\
\text { people to own their identity. }\end{array}$ \\
\hline$R 3$ & $\begin{array}{l}\text { United } \\
\text { Kingdom }\end{array}$ & National & Private & $\begin{array}{l}\text { Large Scale } \\
\text { Impl. }\end{array}$ & B2B Solutions & Economic & $\begin{array}{l}\mathrm{R} 3^{10} \text { is an enterprise } \\
\text { software firm developing } \\
\text { Corda, a distributed ledger } \\
\text { platform designed } \\
\text { specifically for financial } \\
\text { services. }\end{array}$ \\
\hline Guardtime & Estonia & National & Private & $\begin{array}{l}\text { Large Scale } \\
\text { Impl. }\end{array}$ & Health & Social & $\begin{array}{l}\text { Guardtime }^{11} \text { is a technology } \\
\text { platform called KSI that } \\
\text { allows to tackle hard } \\
\text { problems in security, supply } \\
\text { chain, compliance and } \\
\text { networking. }\end{array}$ \\
\hline $\begin{array}{l}\text { Cambridge } \\
\text { Blockchain }\end{array}$ & Luxembourg & National & Private & $\begin{array}{l}\text { Large Scale } \\
\text { Impl. }\end{array}$ & eID & Social & $\begin{array}{l}\text { Cambridge Blockchain's } \\
{ }^{12} \text { distributed architecture } \\
\text { resolves the competing } \\
\text { challenges of transparency } \\
\text { and privacy, leading } \\
\text { to stronger regulatory } \\
\text { compliance, lower costs } \\
\text { and a seamless customer } \\
\text { experiences. }\end{array}$ \\
\hline Loyyal & Norway & National & Private & Pilot & Loyalty Program & Economic & $\begin{array}{l}\text { Loyyal }{ }^{13} \text { is the universal } \\
\text { loyalty and rewards platform, } \\
\text { built with blockchain and } \\
\text { smart contract technology. }\end{array}$ \\
\hline Chroma way & Sweden & National & Private & $\begin{array}{l}\text { Proof-of- } \\
\text { concept }\end{array}$ & Land Registry & $\begin{array}{l}\text { Environmental, } \\
\text { Economic }\end{array}$ & $\begin{array}{l}\text { ChromaWay }{ }^{14} \text { provides } \\
\text { go-to-market solutions for } \\
\text { different financial } \\
\text { sectors. }\end{array}$ \\
\hline Procivis & Switzerland & National & Private & $\begin{array}{l}\text { Proof-of- } \\
\text { concept }\end{array}$ & eID & Social & $\begin{array}{l}\text { Procivis }{ }^{15} \text { was founded by a } \\
\text { clear mission: to empower } \\
\text { individuals everywhere } \\
\text { by providing them with } \\
\text { trusted and compliant digital } \\
\text { identity solutions they can } \\
\text { fully own and control. }\end{array}$ \\
\hline Disc Holding & $\begin{array}{l}\text { United } \\
\text { Kingdom }\end{array}$ & National & Private & $\begin{array}{l}\text { Proof-of- } \\
\text { concept }\end{array}$ & $\begin{array}{l}\text { Blockchain } \\
\text { Provider - } \\
\text { payments }\end{array}$ & Economic & $\begin{array}{l}\text { DISC }^{16} \text { is continuously } \\
\text { developing its own } \\
\text { proprietary applications } \\
\text { in payments, credit and } \\
\text { messaging that demonstrate } \\
\text { and showcase these } \\
\text { attributes and are already } \\
\text { generating } \\
\text { practical benefits for users. }\end{array}$ \\
\hline
\end{tabular}


Table 1. Continued

\begin{tabular}{|c|c|c|c|c|c|c|c|}
\hline $\begin{array}{l}\text { Implementation } \\
\text { Partners }\end{array}$ & Government & $\begin{array}{l}\text { Application } \\
\text { Level }\end{array}$ & $\begin{array}{l}\text { BCT } \\
\text { Type }\end{array}$ & $\begin{array}{l}\text { Technology } \\
\text { Readiness }\end{array}$ & Domain & Impact type & About \\
\hline Credits $^{17}$ & $\begin{array}{l}\text { United } \\
\text { Kingdom }\end{array}$ & National & Public & $\begin{array}{l}\text { Proof-of- } \\
\text { concept }\end{array}$ & $\begin{array}{l}\text { Blockchain } \\
\text { Provider }\end{array}$ & Economic & $\begin{array}{l}\text { CREDITS is an open } \\
\text { blockchain platform } \\
\text { with autonomous smart } \\
\text { contracts and the internal } \\
\text { cryptocurrency. The platform } \\
\text { is designed to create services } \\
\text { for blockchain systems } \\
\text { using self-executing smart } \\
\text { contracts and a public data } \\
\text { registry. }\end{array}$ \\
\hline $\begin{array}{l}\text { Agora Voting // } \\
\text { nvotes }\end{array}$ & Spain & Organisational & Private & Pilot & eVoting & Social & $\begin{array}{l}\text { Electronic voting }{ }^{18} \text { systems } \\
\text { based on blockchain around } \\
\text { the world }\end{array}$ \\
\hline Moni & Finland & National & Public & $\begin{array}{l}\text { Large Scale } \\
\text { Impl. }\end{array}$ & $\begin{array}{l}\text { Finnish } \\
\text { Immigration } \\
\text { Service }\end{array}$ & Economic & $\begin{array}{l}\text { MONI's } \mathrm{s}^{19} \text { technology uses } \\
\text { one of a number of public } \\
\text { blockchains as the means } \\
\text { of transferring value-but } \\
\text { in a way that to the users } \\
\text { seems like } \\
\text { using a debit card. }\end{array}$ \\
\hline e-Law & Estonia & National & Private & $\begin{array}{l}\text { Large Scale } \\
\text { Impl. }\end{array}$ & Legislation & Social & $\begin{array}{l}\text { The e-Law system }{ }^{20} \text { is an } \\
\text { online database for the } \\
\text { Estonian Ministry of Justice } \\
\text { that allows the public to read } \\
\text { every draft law submitted, } \\
\text { using blockchain technology }\end{array}$ \\
\hline $\begin{array}{l}\text { City Of Vienna } \\
(\mathrm{CoV})\end{array}$ & Austria & Municipal & Private & $\begin{array}{l}\text { Proof-of- } \\
\text { concept }\end{array}$ & $\begin{array}{l}\text { Allowance - } \\
\text { Admin process }\end{array}$ & Economic & $\begin{array}{l}\text { Employees of the City of } \\
\text { Vienna }{ }^{21}(\mathrm{CoV}) \text { receive food } \\
\text { tokens in their digital wallets } \\
\text { instead of paper food vouche } \\
\text { for each working day. These } \\
\text { can be redeemed at contract } \\
\text { locations that transfer the } \\
\text { token to the CoV to receive } \\
\text { the value. }\end{array}$ \\
\hline City of Zug & Switzerland & Organisational & Public & Pilot & $\begin{array}{l}\text { e-Voting - } \\
\text { Admin process }\end{array}$ & Social & $\begin{array}{l}\text { The Swiss city launched } \\
\text { an e-voting pilot platform } \\
\text { built on a blockchain as } \\
\text { part of the city's efforts to } \\
\text { embrace the technology. The } \\
\text { voting process took place } \\
\text { between June } 25 \text { and July } \\
1 \text {, and stored both polling } \\
\text { information and residents' } \\
\text { IDs on the system. }\end{array}$ \\
\hline $\begin{array}{l}\text { Valls City } \\
\text { Council }\end{array}$ & Spain & Municipal & Public & $\begin{array}{l}\text { Large Scale } \\
\text { Impl. }\end{array}$ & $\begin{array}{l}\text { Files } \\
\text { Management - } \\
\text { Admin process }\end{array}$ & Social & $\begin{array}{l}\text { Open data portal }{ }^{22} \text { in which } \\
\text { the different data sets and } \\
\text { resources are published both } \\
\text { in the web portal and in a } \\
\text { distributed network based } \\
\text { on IPFS (data persistence). } \\
\text { At the same time data is } \\
\text { accountable by logging all } \\
\text { changes on a distributed, } \\
\text { immutable database } \\
\text { (Ethereum)Improve citizen } \\
\text { participation. Reinforce } \\
\text { commitment with citizens. } \\
\text { Security and resilience }\end{array}$ \\
\hline City of the Hague & Netherlands & Municipal & Public & Pilot & $\begin{array}{l}\text { Subsidy - Admin } \\
\text { process }\end{array}$ & Environmental & $\begin{array}{l}\text { Develope }{ }^{23} \text { a significantly } \\
\text { improved (and highly } \\
\text { automated) regulation } \\
\text { for subsidies on electric } \\
\text { vehicles. }\end{array}$ \\
\hline
\end{tabular}


Table 1. Continued

\begin{tabular}{|c|c|c|c|c|c|c|c|}
\hline $\begin{array}{l}\text { Implementation } \\
\text { Partners }\end{array}$ & Government & $\begin{array}{l}\text { Application } \\
\text { Level }\end{array}$ & $\begin{array}{l}\text { BCT } \\
\text { Type }\end{array}$ & $\begin{array}{l}\text { Technology } \\
\text { Readiness }\end{array}$ & Domain & Impact type & About \\
\hline $\begin{array}{l}\text { Belfius Bank \& } \\
\text { Insurance }\end{array}$ & Belgium & National & Private & $\begin{array}{l}\text { Large Scale } \\
\text { Impl. }\end{array}$ & $\begin{array}{l}\text { Allowance/ } \\
\text { subsidy - public } \\
\text { service }\end{array}$ & $\begin{array}{l}\text { Economic, } \\
\text { Environmental }\end{array}$ & $\begin{array}{l}\text { Rewarding }{ }^{24} \text { children who } \\
\text { go to school by foot/bike } \\
\text { with tokens that are usable } \\
\text { at the local fair or shops. } \\
\text { Collaboration between local } \\
\text { governement, school and } \\
\text { Belfius Bank.Create a safer } \\
\text { school environment Guide } \\
\text { children over the safest roads } \\
\text { to school. }\end{array}$ \\
\hline $\begin{array}{l}\text { BAR } \\
\text { Organization } \\
\text { Gemeente } \\
\text { Barendrecht } \\
\text { Gemeente } \\
\text { Albrandswaard } \\
\text { Gemeente } \\
\text { Ridderkerk }\end{array}$ & Netherlands & Organisational & Public & Pilot & $\begin{array}{l}\text { Licensing - } \\
\text { public service }\end{array}$ & Economic & $\begin{array}{l}\text { The municipalitie } \mathrm{e}^{25} \mathrm{~s} \text { of } \\
\text { Barendrecht, Albrandswaard } \\
\text { and Ridderkerk's BAR } \\
\text { Organization looked into } \\
\text { ways in which they could } \\
\text { apply blockchain to various } \\
\text { permitting processes such } \\
\text { as street parties. The BAR } \\
\text { organization looked at small- } \\
\text { scale events where someone } \\
\text { applies for a license for a } \\
\text { street party. }\end{array}$ \\
\hline $\begin{array}{l}\text { Digipolis } \\
\text { Antwerpen }\end{array}$ & Belgium & Municipal & Private & $\begin{array}{l}\text { Large Scale } \\
\text { Impl. }\end{array}$ & $\begin{array}{l}\text { Personal data } \\
\text { management }\end{array}$ & Social & $\begin{array}{l}\text { This ACPaaS }{ }^{26} \text { Privacy } \\
\text { engine uses blockchain } \\
\text { technology. It's an innovative } \\
\text { concept, whereby the } \\
\text { engine functions as a } \\
\text { gateway or middleware and } \\
\text { subsequently protects all } \\
\text { privacy-sensitive services } \\
\text { and data. }\end{array}$ \\
\hline $\begin{array}{l}\text { Municipality of } \\
\text { Groningen }\end{array}$ & Netherlands & Municipal & Public & $\begin{array}{l}\text { Large Scale } \\
\text { Impl. }\end{array}$ & $\begin{array}{l}\text { Allowance/ } \\
\text { subsidy - public }\end{array}$ & Social & $\begin{array}{l}\text { Stadjerspas }{ }^{27} \text { is a fully } \\
\text { operable service which uses } \\
\text { blockchain infrastructure to } \\
\text { provide discounted services } \\
\text { to low-income citizens of the } \\
\text { Municipality of Groningen. } \\
\text { Promotion of inclusivity } \\
\text { in the city via a voucher } \\
\text { system started in 1994. Up } \\
\text { until } 2013 \text { vouchers were } \\
\text { completely paper-based. }\end{array}$ \\
\hline $\begin{array}{l}\text { Gemeente } \\
\text { Utrecht }\end{array}$ & Netherlands & Municipal & Private & Pilot & $\begin{array}{l}\text { Waste } \\
\text { mangement }\end{array}$ & $\begin{array}{l}\text { Economic, } \\
\text { Environmental }\end{array}$ & $\begin{array}{l}\text { The city of Utrecht }{ }^{28} \text { is } \\
\text { piloting blockchain for } \\
\text { 'waste processing'. The } \\
\text { city believes apparent } \\
\text { that organization of the } \\
\text { waste processing in the } \\
\text { blockchain could bring many } \\
\text { benefits. Specifically, the } \\
\text { way in which waste weight } \\
\text { per empty container is } \\
\text { registered. In the pilot, the } \\
\text { waste weight data is linked } \\
\text { to that of the transporters, } \\
\text { intermediaries and final } \\
\text { processors, and organized } \\
\text { via the blockchain. All } \\
\text { these parties keep their own } \\
\text { administration. }\end{array}$ \\
\hline $\begin{array}{l}\text { Regione } \\
\text { Lombardia }\end{array}$ & Italy & Regional & Public & Pilot & $\begin{array}{l}\text { Allowance/ } \\
\text { subsidy - } \\
\text { payments }\end{array}$ & Social & $\begin{array}{l}\text { A public service }{ }^{29} \text {, using } \\
\text { blockchain technologies, } \\
\text { which offers families from } \\
\text { deprived backgrounds free } \\
\text { access to childcare for } \\
\text { children up to the age of } 3 \text {. }\end{array}$ \\
\hline
\end{tabular}


Table 1. Continued

\begin{tabular}{|c|c|c|c|c|c|c|c|}
\hline $\begin{array}{l}\text { Implementation } \\
\text { Partners }\end{array}$ & Government & $\begin{array}{l}\text { Application } \\
\text { Level }\end{array}$ & $\begin{array}{l}\text { BCT } \\
\text { Type }\end{array}$ & $\begin{array}{l}\text { Technology } \\
\text { Readiness }\end{array}$ & Domain & Impact type & About \\
\hline $\begin{array}{l}\text { Gemeente } \\
\text { Zuidhorn }\end{array}$ & Netherland & Municipal & Private & Pilot & $\begin{array}{l}\text { Allowance/ } \\
\text { subsidy - } \\
\text { payments }\end{array}$ & Social & $\begin{array}{l}\text { The Child Package }{ }^{30} \text { is } \\
\text { a budget for children of } \\
\text { parents with a minimum } \\
\text { income. In the municipality } \\
\text { of Zuidhorn about } 150 \\
\text { children are eligible for the } \\
\text { program. This money is } \\
\text { used by the municipality } \\
\text { for disadvantaged children, } \\
\text { giving them the opportunity } \\
\text { to participate in social } \\
\text { activities, in sports and } \\
\text { cultural activities at school. } \\
\text { The municipality carries } \\
\text { out this national assignment } \\
\text { with local entrepreneurs and } \\
\text { associations. }\end{array}$ \\
\hline Ville de Lyon & France & Municipal & Private & $\begin{array}{l}\text { Large Scale } \\
\text { Impl. }\end{array}$ & $\begin{array}{l}\text { Allowance/ } \\
\text { subsidy - } \\
\text { payments }\end{array}$ & Social & $\begin{array}{l}\text { The calculation }{ }^{31} \text { of the } \\
\text { municipal family quotient is } \\
\text { used to obtain reductions on } \\
\text { the price of school canteen } \\
\text { meals in public or private } \\
\text { schools, on the prices of } \\
\text { Divertisport activities, } \\
\text { Lyon Wednesdays, Friday } \\
\text { afternoons and transplanted } \\
\text { classes. It is determined } \\
\text { based on income and family } \\
\text { composition. }\end{array}$ \\
\hline$A N S A$ & Italy & Organisational & Public & $\begin{array}{l}\text { Large Scale } \\
\text { Impl. }\end{array}$ & Fake news & Social & $\begin{array}{l}\text { ANSA's }{ }^{32} \text { objective is to } \\
\text { strengthen bonds of trust } \\
\text { between its organization and } \\
\text { its readers and customers, } \\
\text { using blockchain technology } \\
\text { that shows the source of } \\
\text { news. The new ANSA } \\
\text { solution is based on EY } \\
\text { OpsChain Traceability } \\
\text { technology, characterized by } \\
\text { public transactions recorded } \\
\text { on the Ethereum blockchain. }\end{array}$ \\
\hline
\end{tabular}


Charalampos (Harris) Alexopoulos is an Adjunct Lecturer of Open, Big and Linked Data Management at the Department of Information and Communications Systems Engineering of the University of the Aegean. He is also a Researcher in the Information Systems Laboratory of the same department, publishing on open data, decision support, smart cities, and e-government.

Yannis Charalabidis is Full Professor of Digital Governance at the Department of Information and Communication Systems Engineering, University of the Aegean, based in Samos, Greece. He is the founding director of the Digital Governance Research Centre, coordinating policy making, research and application projects for governments and enterprises worldwide. He is heading the Innovation and Entrepreneurship Unit of the Aegean University, and the MSc on Digital Innovation and Entrepreneurship, in collaboration with National Technical University of Athens. He has more than 25 years of experience in designing, implementing and managing complex information systems, 10 of which as executive director in SingularLogic Group, leading the 500-staff software products unit and its expansion in Greece and Europe. He has published more than 10 books and 300 papers in international journals and conferences, and actively participates in international scientific and policy making bodies. Yannis has been teaching as an invited professor at UC Berkeley, TU Delft, Stevens Institute NY, State University NY, University of Washington, City University Hong Kong, Swinburne University Melbourne and Wollongong University in Australia. In 2016, he was ranked as the 8th most prolific author in Digital Government, among 10,000 authors of the domain, by the Washington University survey. In 2018, he was included in the "100 most influential people in Digital Government", by Apolitical Group.

Michalis Avgerinos Loutsaris is a Postgraduate Student in "Digital Innovation and Entrepreneurship," Department of Information and Communication Systems Engineering, University of the Aegean, Greece. Michalis holds a Bachelor Degree from University of the Aegean, Department of Information and Communication Systems Engineering. His research interests involve around Artificial Intelligence and Text Mining. He is Lab Assistant and has some experience in teaching lab courses as assistant. He is member of the Information Systems Laboratory (ISLab) and is working in several lab projects.

Zoe Lachana (female) is a Ph.D. Candidate in the University of the Aegean. She holds a Bachelor Degree and a Master of Science in "Technologies and Management of Information and Communication Systems" from the University of the Aegean, Department of Information and Communication Systems Engineering. Her research interests involve around eGovernment, Artificial Intelligence and Text Mining. She is Lab Assistant and has some experience in teaching lab courses as an assistant. She is a member of the Information Systems Laboratory (ISLab) and is working on several lab projects. 